\title{
Macrorhabdus ornithogaster in ostrich, rhea, canary, zebra finch, free range chicken, turkey, guinea-fowl, columbina pigeon, toucan, chuckar partridge and experimental infection in chicken, japanese quail and mice
}

[Macrorhabdus ornithogaster em avestruzes, ema, canário, mandarim, galinha, peru, galinha da Angola, pombo doméstico, rolinha, tucano, perdiz de chuckar e infecção experimental em galinha, codorna e camundongo]

\author{
N.R.S. Martins ${ }^{1 *}$, A.C. Horta ${ }^{1}$, A.M. Siqueira ${ }^{2}$; S.Q. Lopes $^{3}$; J.S. Resende ${ }^{1}$, M.A. Jorge ${ }^{4}$, R.A. Assis ${ }^{1}$, \\ N.E. Martins ${ }^{1}$, A.A. Fernandes ${ }^{1}$, P.R. Barrios ${ }^{1}$, T.J.R. Costa ${ }^{1}$, L.M.C. Guimarães ${ }^{1}$ \\ ${ }^{1}$ Escola de Veterinária - UFMG \\ Caixa Postal 567 \\ 30123-970 - Belo Horizonte, MG \\ ${ }^{2}$ IBAMA \\ ${ }^{3}$ Médico veterinário autônomo \\ ${ }^{4}$ EMBRAPA/EPAMIG.
}

\begin{abstract}
Since 2000, Macrorhabdus ornithogaster "megabacteriosis" has been diagnosed in the avian diseases laboratory in a diversity of avian species and varied spectrum of disease. The disease in some species (chickens, turkeys, guinea fowls) was clinically characterized by emaciation, prostration, loss of appetite, cachexia and death, with a typically chronic course. A more acute disease was observed in finches (canary-Serinus and zebra-Taeniopygia) and budgerigars (Melopsittacus undulatus). The large rod shaped organism, visible from 100 times magnification, with and without staining, could be detected in sick and also in reasonably normal individuals of some species, such as chickens, turkeys, quails and pigeons. In rheas (Rhea americana), ostriches (Struthio camelus), canaries, zebra-finches, guinea-fowl (Numida meleagris) and budgerigars. The disease was severe, causing to up to $100 \%$ mortality. The infection could be detected in some species along with other infectious or disease problems, such as endoparasites (helminths, coccidia) and ectoparasitism (order Mallophaga or/and order Acarina). The cultivation of $M$. ornithogaster was successfully achieved in solid and liquid media, originated from chickens (four isolates), guinea fowl ( 1 isolate), chuckar partridge ( 1 isolate) and canary ( 1 isolate). A very interesting finding at microscopy was motility of $M$. ornithogaster, as detected both in cultures obtained on agar for pathogenic fungi and passaged into thioglycolate broth, as well as on samples observed in wet preparations from in vivo. Differences in colony aspects were noted among the isolates. Experimental infections were attempted in chicken and japanese quail, using a chicken isolate, allowing the detection of the organism in the proventriculus and liver in apparently normal birds. One chicken isolate was injected intraperitoneally in Balb/c mice and resulted in $100 \%$ mortality.
\end{abstract}

Keywords: Macrorhabdus ornithogaster, megabacteria, ostrich, rhea, canary, budgerigar, zebra finch, industrial broiler, free range chicken, turkey, guinea-fowl, domestic pigeon, ruddy ground-dove, toucan, chuckar partridge

\section{RESUMO}

Desde 2000, diversos casos de infecção e doença por Macrorhabdus ornithogaster (megabacteria) foram diagnosticados no Setor de Doenças das Aves (Escola de Veterinária da UFMG). A doença clínica foi caracterizada por emagrecimento, prostração, perda do apetite, caquexia e morte, em curso crônico, embora com forma mais aguda em canários e periquitos. O microrganismo grande, em forma de bastão, visivel a partir de 100 aumentos sem e com coloração, pode também ser detectado em aves de aspecto

Recebido em 31 de outubro de 2005

Aceito em 19 de maio de 2006

E-mail: rodrigo@vet.ufmg.br 
clínico normal, principalmente galinhas, perus, codornas e pombos. Em emas (Rhea), avestruzes (Struthio camelus), canários, mandarins, galinhas da Angola (Numida meleagris) e periquitos Australianos (Melopsittacus undulatus), a severidade da doença foi sempre maior, ocasionando até 100\% de mortalidade em alguns plantéis. Na maioria das espécies a doença foi detectada em aves com endo elou ectoparasitismo. $O$ cultivo de M. ornithogaster foi obtido em meio sólido (ágar para fungos patogênicos) e subcultivado em meio líquido (thioglicolato), do proventriculo de galinha, galinha da Angola, perdiz de chuckar e canário. O resultado mais surpreendente na microscopia de M. ornithogaster foi a presença de motilidade, detectada tanto de cultivos in vitro quanto de preparações úmidas de in vivo. Diferenças nos aspectos das colônias foram notadas entre os isolados. Infecções experimentais em galinha (SPF) e codorna japonesa permitiram a detecção do organismo nos proventrículos das aves de aspecto normal. Nas codornas, à necropsia notaram-se hemorragias hepáticas. A infecção experimental em camundongos via intraperitoneal resultou em $100 \%$ de mortalidade, também com lesões hepáticas. Aspectos do cultivo, a importância da doença, as espécies de aves susceptiveis e seu papel na epidemiologia são discutidos.

Palavras-chave: Macrorhabdus ornithogaster, megabacteria, avestruz, ema, canário, mandarim, frango de corte industrial; galinha de fundo de quintal, peru, galinha da Angola, pombo doméstico, rolinha, tucano, perdiz de chuckar

\section{INTRODUCTION}

Megabacteriosis is a gastric yeast infection that has been described worldwide affecting several species of class $A V E S$, including canaries (Van Herck et al., 1984), budgerigars (Scanlan and Graham, 1990; Henderson et al. 1988; Baker et al., 1992; Filippich \& Hendrikz, 1998; Pennycott et al., 1998; ostriches (Huchzermeyer et al., 1993; Baker, 1997) chickens (Mutlu, 1997; Schulze \& Heidrich, 2001) and turkeys (Schulze and Heidrich, 2001). The large organism has been shown to measure about $1.5-3.0 \mu \mathrm{m}$ in diameter and $20-50 \mu \mathrm{m}$ in length, staining weakly basophilic by $\mathrm{H} \& \mathrm{E}$ and positive periodic acid reaction (Scanlan and Graham, 1990). More recent reports propose its classification as Macrorhabdus ornithogaster (Tomaszewski et al., 2003; Phalen \& Moore, 2003; Phalen, 2005), an anamorphic ascomycetous yeast. The objective of this study was to report the occurrence of natural megabacteriosis in a wider range of avian species attempting the cultivation of the yeast, to correlate infection and disease and to produce an experimental infection in order to address inter-species infection and susceptibility.

\section{MATERIALS AND METHODS}

Clinical materials of natural megabacterosis in ostrich (Struthio camelus), rhea (Rhea americana), canary (Serinus canarius), zebra finch (Taeniopygia guttata), broiler and free range chicken (Gallus gallus formadomestica), turkey (Meleagris gallopavo formadomestica), guinea-fowl (Numida meleagris), domestic pigeon (Columba livia), Ruddy Ground-dove (rolinha - Columbina talpacoti), toucan (Ramphastos toco), chuckar partridge (Alectoris chuckar) were obtained from routine disease diagnosis (sick birds) or collected for diagnosis of infection, at the avian diseases laboratory, Escola de Veterinária, UFMG, Belo Horizonte, Minas Gerais, Brazil. Experimental infections in Japanese quail (Coturnix japonica) and mice was achieved using chicken megabacteria. All specimens were examined by necropsy and samples were taken for direct microscopy visualization, histology and microbiology.

Direct microscopy of fresh impression smears of ventriculus or proventriculus mucosae were prepared onto glass slides and observed unstained and stained by Giemsa or Gram at the microscope. Proventriculus and gizzard tissue sections were obtained and fixed by saline buffered formaldehyde $10 \%$ for histopathology. Some fecal materials were also taken for microscopy.

Culture of ventricular or proventricular mucosa samples were made in Sabouraud's agar or selective agar for pathogenic fungi ${ }^{1}$ in sealed Petri dishes or in a 5\% carbon dioxide atmosphere. Subcultures were made in thioglycolate medium. Slide samples were heat or methanol fixed for staining by Giemsa or Gram for microscopy. Motility was evaluated from broth cultures observed with the hangingdrop method. 
Using a chicken isolate (of a naturally infected free-range chicken) an experimental infection of 10 Japanese quails (Coturnix japonica), 45 daysold, was performed, with material collected from the proventriculus (washings). Cultures of the chicken isolate were also used for the infection of five SPF chickens (30 days-old), after five in vitro passages. Balb/c mice were intraperitoneally inoculated with the chicken isolate $\left(10^{7} \mathrm{cfu} / 0,1 \mathrm{ml}\right)$.

\section{RESULTS AND DISCUSSION}

Ostriches hatched on 06/06/2000 and imported from Spain on 02/10/2000 into Brazil were raised in a ratite farm up to $13 / 10 / 2000$, when mortality started. The flock presented a clinical evolution including uneven growth, depression, fasting, leg problems and the pathology aggravated up to mortality. Deaths were reported on October 13, 14, 28, 30 and 31 and on November 6 and 8, 2000. Treatments given to the animals included forced oral hydration and feeding with tubing (electrolytes, flour mixture and energy sources). Animals with gastric impaction were treated with laxative medication. At necropsy, ulcers were noted on the gizzard mucosa (Fig. 1a). Impression smears were made and stained by Giemsa for microscopic examination. Long rod-shaped organisms were observed at 400 and 1000 times magnification (Fig. 1b). The characteristics of the disease and shape of the organisms found in the ulcerated gastric mucosa suggested the diagnosis of megabacteriosis. Megabacteriosis in ostriches has been detected in Brazil (Marinho et al., 2004) and indicates for the necessity of further studies on the epidemiology and risk for the increasing ratite farming.

Budgerigars with gradual emaciation and mortality were detected by the owner in a high standard and genetic quality budgerigar raising facility. Birds presented diarrhea and accumulation of dried feces at the cloacal surroundings, in some individuals forming a packed obstruction or plug. Dead birds were necropsied and a dramatic atrophy of the pectoral muscles was observed, with hemorrhages on the proventricular mucosa next to the transition to the gizzard. Impression smears were made and stained by Giemsa and very large rod-shaped organisms were observed (Fig. 2). According to the literature (Scanlan and Graham, 1990, Baker, 1992; Rosskopf, 1996), megabacteriosis includes thinning and diarrhea, hemorrhage of the proventriculus and the presence of the characteristic large rod-shaped organisms. Megabacteriosis may have been a disease problem for already a certain time in budgerigars in Brazil, although very rarely reported. Owners have not generally resort to the veterinarian or laboratory assistance, and professionals may not be aware of the occurrence of the disease in our environment, which may explain the scarcity of previous reports. The medication of birds with only reasonable success using Amphotericin B plus a large spectrum antibiotic (a quinolone) was reported by the owner. Untreated individuals (four) maintained in quarantine in our laboratory did not survive.

In canaries, an outbreak of disease characterized by emaciation and mortality in a bird growing facility in which a megabacteriosis-like disease in budgerigars was observed (described above) and might have cursed simultaneously were studied. Canaries underwent severe emaciation and dead individuals were submitted to diagnosis. Fig. $3 \mathrm{a}, 3 \mathrm{~b}$ and $3 \mathrm{c}$ illustrate some aspects of the disease. Emaciated birds presented atrophy of the breast muscles (Fig. 3a). Giemsastained impression smears examined at microscopy enabled the observation of the very large rod-shaped organism. The organisms were packed and disposed in palisade, as observed at high concentrations in impression smears made of various proventricular regions (Fig. 3b). Histologic sections of proventriculus showed the colonization into the crypts of the proventricular mucosa (Fig. 3c). Other two outbreaks in canary ${ }^{1}$ flocks of independent growers were observed, both with similar high mortality. For one grower (a veterinarian), a therapy based on a combination of antimicoties (instating and cetocomized) was successful for reducing mortality although not at advanced disease.

A zebra finch was submitted to diagnosis from a bird grower which had a history of canaries undergoing emaciation and death in which a diagnosis of megabacteriosis was made. The bird was emaciated at arrival for necropsy (Fig. 4a). The pectoral muscles were atrophied (Fig. 4b). At necropsy, gizzard ulcerations could be noted

${ }^{1}$ Merck, Alemanha 
(Fig. 4c). Histopathology (H\&E) of the gizzard mucosa enabled the visualization of massive clumps of re-ornithogaster attached to the epithelium (Fig. 4d).

Broiler chickens from flocks showing depressed growth performance were examined for "megabacteria" in the proventriculus. The broilers were raised in a farm with other health problems, notably Marek's disease in some individuals, possibly due to failure in vaccination. The microorganism was found at a less abundant infection than free-range chickens. Sick free-range chickens were submitted to diagnosis and the clinical history included emaciation, prostration (Fig. 5a), loss of production and occasional mortality. Living chickens were cachetic and moderately prostrated. At necropsy, proventricular changes were observed, such as enlargement (Fig. 5b) and glands were hypertrophic and irregular (Fig. 5c). Impression smears stained by Giemsa revealed very large rod-shaped organisms (Fig. $5 \mathrm{~d})$. Cultures were produced from mucosal swabbing and stained by Giemsa or Gram.

The large rod shaped organisms were observed in Japanese quail, European quail and chuckar partridge. Quails did not present an overt disease, although the European quails did seem to show a slight reduction in growth. Chuckar partridges were submitted to necropsy due to mortality at the confinement. Upon the visualization of $M$. ornithogaster at the proventriculus of the chuckar partridge, a culture was succesfully obtained in agar for pathogenic fungi ${ }^{1}$. An experimental infection in Japanese quail (Coturnix japonica) was performed using mucosal extracts of chicken proventriculus (the actual free range chicken photographed and described previously), in quails in which $M$. ornithogaster was not previously detected in feces. The infection in quails did not result in an overt clinical disease, although a perceptible loss of muscular mass could be seen after 30 days post infection. At necropsy, enlarged proventriculus with milky secretion (Fig. 6a) and eroded gizzard koilin layer (Fig. 6a), where the organism could be detected were observed (Fig. 6b). In the liver hemorrhages were seen (Fig. 6c).

An outbreak of disease in a rhea growing farm starting on November $6^{\text {th }} 2002$, characterized by a severe clinical disease and $50 \%$ mortality in a three-day clinical course was studied. Sick rheas were prostrated and remained apart of the rest of the flock. Therapy applied included hydration and vitamins with no apparent beneficial effect. At necropsy the severe emaciation could be noted (Fig. 7a) and cachexia demonstrated by the reduction of the cardiac fat (Fig. 7c). Hemopericardium was observed and contained a large collection of hemorrhage fluid (7b). Ulcerations in the proventriculus and ventricular impaction were observed (Fig. 7d) and mucosal slide smears enabled the visualization of the large organism (Fig. 7e).

A free-range flock of guinea fowl was affected by a disease characterized by a severe cachexia and $100 \%$ mortality. Post mortem examination revealed a cortex wasting disease which resulted in severe reduction of the muscular mass, the 'going light' syndrome, especially the atrophy of pectoral muscles. At necropsy, ulcerations on the gizzard mucosa and petechial hemorrhages on the proventricular mucosa (Fig. 8) were observed. The direct examination of the mucosa by impression smears enabled the visualization of the very large rod organisms (Fig. 8b). The cultivation on agar for pathogenic fungi (Fig. 8c) obtained whitish mucoid colonies, for instance, different from those formed by the chicken isolate. The visualization at microscopy of direct impression smears (proventriculus) or cultures revealed a great pleomorphism, being the cultured organism several times smaller (Fig. 8d).

Five individuals of free living Columbina talpacoti and Columba livia were captured in the urban area of Belo Horizonte, MG, Brazil, and examined for the presence of $M$. ornithogaster in feces and directly from the proventricular mucosa. Very few organisms found were considered indicative for $M$. ornithogaster. Although sampling was not sufficient for determining the occurrence in these species, some inference may be drawn. All Columbina talpacoti collected were healthy individuals and that may be a reason for not finding abundant infection. Columba livia specimens were also captured due to some other health problems, such as Trichomoniasis, intoxication or trauma. Columbina and Columba poor infection by $M$. ornithogaster, as detected, might indicate a natural resistance, but the epidemiological importance of that scarce infection may be 
relevant in the role of natural reservoir, if that condition becomes confirmed.

An outbreak of coccidiosis (Eimeria) in a flock of Ramphastos toco kept in captivity with high mortality (close to $100 \%$ ) rendered the examination also for $M$. ornithogaster. Proventriculi were examined at microscopy as described and abundant very large rod-shaped organisms were observed (no picture available). The infection in toucans, although in the concurrent case with a severe coccidiosis, might represent an important cause of disease and mortality.

Isolates were obtained from chicken, guinea fowl, chuckar partridge and canary. Cultures were successfully grown at $37^{\circ} \mathrm{C}$ with sealed plates, but more exuberant at 5\% CO2 (Fig. 9a). It was interesting to notice the dark pigmentation of the chicken isolate but no pigmentation of the Guinea fowl or chuckar isolates (Fig. 9b and 9c). For all isolates a marked reduction in size was noted for organisms grown in vitro, as compared to those detected in vivo, at direct microscopy of the proventricular mucosa (Fig. 10a and b). Large forms were abundant and also visible in vitro. A very interesting finding which was noticed after sub-cultivation in liquid medium (thioglycolate), not previously described, was that $M$. ornithogaster is a motile organism. The smaller bacilli in vitro were motile by screw-type rotation movements, which might indicate a polar organelle or flagellum, and for the very large forms, mostly seen in vivo, a smooth linear forward or still lateral contortion movements were observed. The movement was rapidly obliterated by cooling off the slide. For the in vivo observation of motility, wet preparations of proventricular scraping or feces in slide with coverslip were made with saline at room temperature. Mortility was also evaluated by needle inoculating organ (tube) observing widespread turbidity. Gas was produced by all the cultures. The small of the colonies resembled that of yeast extract.

The experimental infection of mice (IP) resulted in $100 \%$ mortality, and the large dose given $\left(10^{3}\right.$ cfu/dose) might be the reason for that. Further experimentation in mice will be performed with all the isolates in order to evaluate pathogenicity.

Evidence has been collected in this report which enables the assumption that megabacteriosis is widespread in some free range domestic and companion avian species and might be of importance for industrial chickens. The variety of species and environments might also suggest that transmission may occur across species and is facilitated by the lack of a conventional biosecurity policy. This fact may be supported by the occurrence of disease in zebra finches and canaries of a property or in budgerigars and canaries of another property, or in addition, by the transmission experiments from chicken to Japanese quail, resulting in colonization, disease and lesions in the recipient (Japanese quail) species and to mice, with $100 \%$ mortality. The experimental infection of mice using the chicken isolate may be an indication of the pathogenicity of the isolate. A preliminary investigation in stunted broiler and layer chickens of the poultry industry, which enabled the detection of $M$ ornithogaster in the proventriculi, did not permit a knowledge of the occurrence and impact of the infection, but might recommend for an attention on the subject for industrial chickens.

Interesting findings were observed from cultures. Cultures were obtained from free-range chicken, Guinea fowl, Chuckar partridge and canary. The chicken isolate of Macrorhabdus ornithogaster was the only culture to express colonies with dark pigmentation. The observation of different culture aspects of ornithogaster isolates may indicate different types or strains. In vitro cellular forms, as observed from agar or broth cultures, were much smaller than in vivo observations.

The most surprising finding for the organism was motility. Fungi may present spore motility by flagella. However, motility for M. ornithogaster were also seen as cellular lateral "swinging" or linear forward movements, which might recommend Macrorhabdus for another kingdom other than Fungi. Motility will deserve a more profound study of the organelles involved and should includ electron microscopy. 
Figure 1a. Ostrich: Ulcerative lesion (recent) on the ventricular mucosa in a 5 months-old ostrich. Note the epithelial perforations reach the submucosa (arrow). Figure 1b: M. ornithogaster (arrow) stained by Giemsa and viewed at the microscope (1000x).

Figure 2: Budgerigar: Photomicrograph of budgerigar proventricular megabacteria (arrows) as stained by Giemsa (1000x).

Figure 3a: Canary: Emaciated canary with breast feathers dislocated to show the atrophy of pectoral muscles (arrow). Figure 3b: Packed megabacteria of impression smear observed at immersion microscopy (1000x). Fig.3c: Histopathology of proventriculum showing megabacteria (arrows) densely colonized mucosa (400x).

Figure 4a: Zebra finch: Prostrated zebra-finch (Taeniopygia guttata). Figure 4b: Note the sharp-edged sternum due to the pectoral muscular atrophy. Fig.4c: Picture of gizzard with erosions and ulcers. Figure 4d: Packed megabacteria (arrow; proventriculus; histology; H\&E; 100x).

Figure 5a: Depressed free-range chicken shown to be infected by megabacteria. Figure 5b: Enlarged chicken proventriculus. Figure 5c: Hypertrophied proventricular glands (arrow). Figure 5d: Large rodshaped organism from proventriculus impression smear (arrows); 1000x.

Figure6a: Japanese quail: Eroded gizzard koilin layer (arrow) and milky secretion on the proventriculus (stars). Figure 6b: Proventricular mucosa of Japanese quail: note rod shaped organisms (arrows) visible (400x) on impression smear without staining. Figure 6c: Quails given megabacteria-containing mucosal extracts: hemorrhages in the liver. Figure 6d: Culture in agar for pathogenic fungi: note chromogenesis of growth (chicken origin).

Figure 7a: Emaciated rhea. Figure 7b: Hemopericardium Figure 7c: Heart of rhea with consumed cardiac fat during cachexia. Figure 7d: Proventricular ulceration and ventricular impaction. Figure 7e: Unstained image of proventricular mucosa smear showing the rod-shaped organism (arrows).

Figure 8a: Guinea fowl: Petechial hemorrhages visible at the mucosa of proventriculus. Figure 8b: Culture of megabacteria in agar for pathogenic fungi: note the non-chromogenic culture, as compared to the chicken isolate in Figure 8c: Microscopy at 400x magnification of direct impression of proventricular mucosa. Figure 8d: Microscopy at 400x after culture in agar for pathogenic fungi.

Figure 9: Cultivation of Macrorhabdus ornithogaster in Agar for Pathogenic Fungi (Merck). Figure 9a: Aspect of colony: note that colonies obtained from a chicken isolate are brownish. Figure 9b: Cultivation of an isolate from Guinea fowl expressed whitish colony.

Figure 10: Pleomorphism of M. ornithogaster; Figure 10a: Visualization of direct proventricular inprint at 1000x; Figure 10b: Visualization of the cultured organism. Pictures were taken before and after the cultivation from chicken (hen). 
Macrorhabdus ornithogaster...
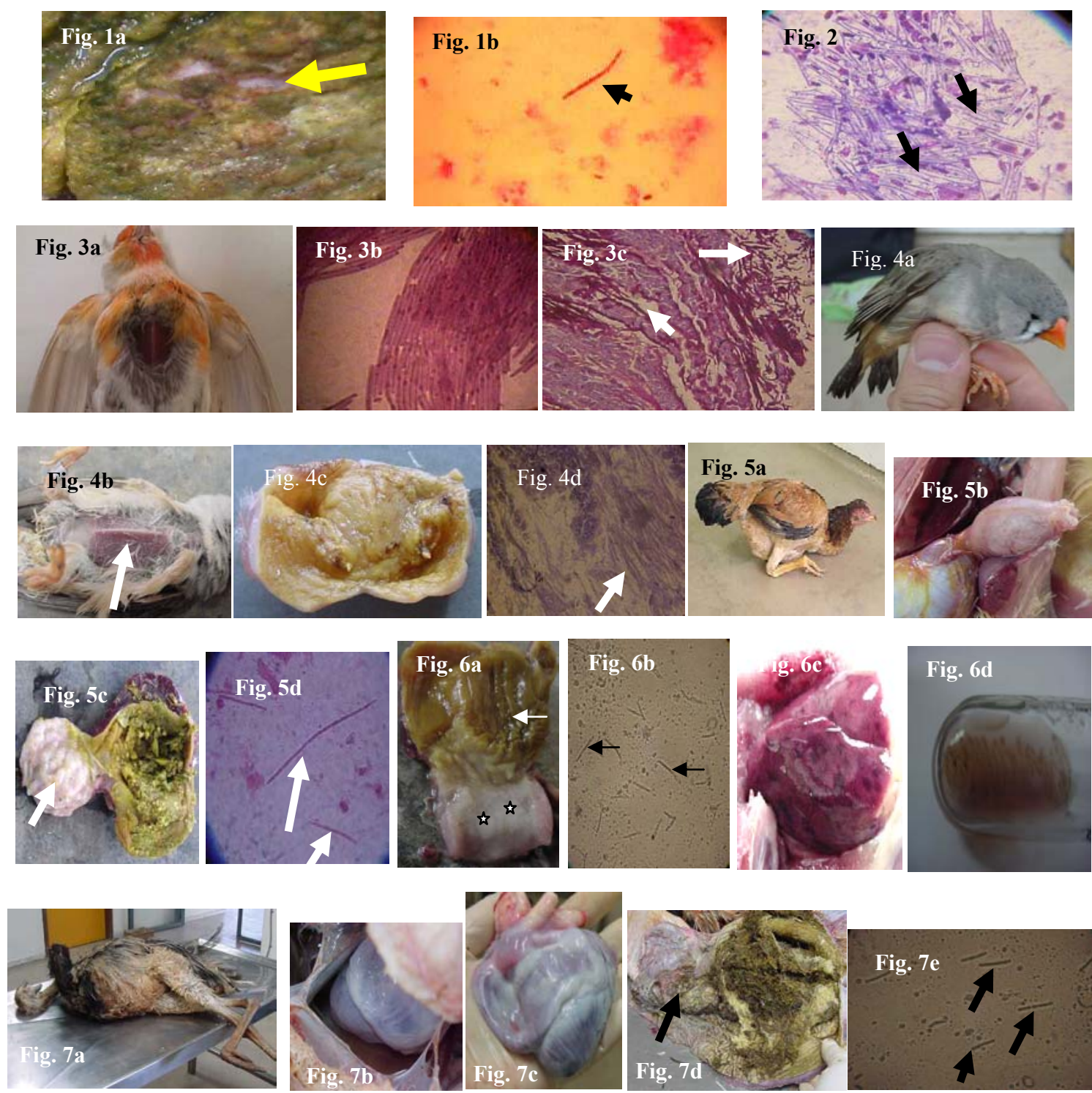

Fig. $7 \mathrm{e}$
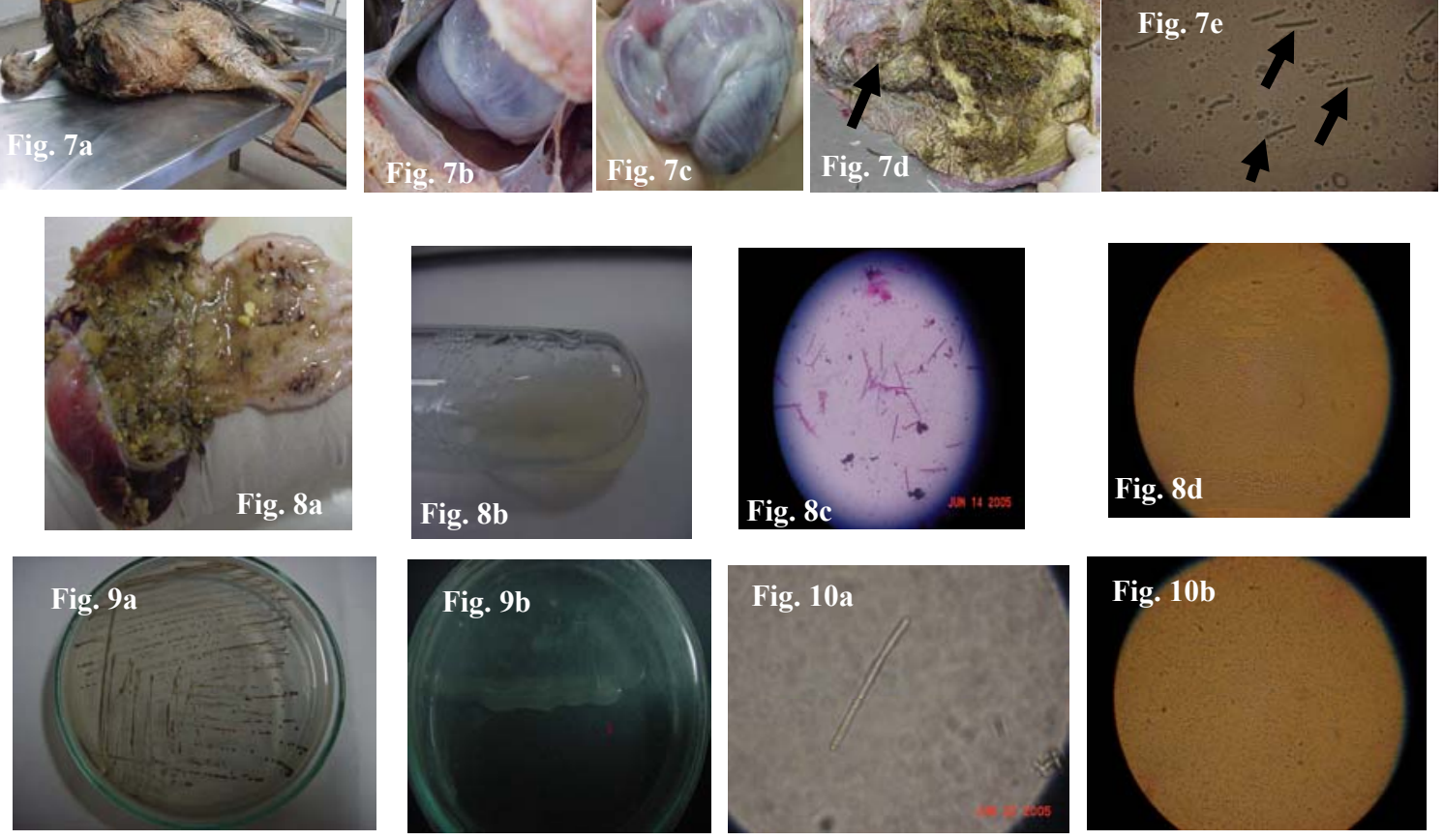


\section{ACKNOWLEDGEMENT}

The authors are grateful to Prof. Ênio Medeiros Cunha, for providing some budgerigar and canary clinical specimens, to $\mathrm{Mr}$. Ricardo Canesso Dalla Rosa for staining and Mr. Cláudio Rocha Públio for laboratory support.

\section{REFERENCES}

BAKER, J.R. Megabacteria in diseased and healthy budgerigars. Vet. Rec., v.140, p. 627, 1997.

BAKER, J.R. Megabacteriosis in exhibition budgerigars. Vet. Rec., v.131, p.12-14, 1992.

COOK, S. Role of Megabacteria in mammals [letter]. Vet. Rec., v. 146, p. 444, 2000.

FILIPPICH, L.J.; HENDRIKZ, J.K. Prevalence of megabacteria in budgerigar colonies. Aust. Vet. J. v. 76, p. 92-95, 1988.

GERLACH, H. Megabacteriosis. Semin. Avian Exotic. Pet. Med., v.10, p.12-19, 2001.

HENDERSON, G.M.; GULLAND, F.M.D.; HAWKEY C.M. Haematological findings in budgerigars with megabacterium and trichomonas infections associated with 'going light'. Vet. Rec., v. 123, p.492-494, 1988.

HUCHZERMEYER, F.; HENTON M. Megabacteria in mammals [letter]. Vet. Rec., v.146, p.768, 2000.

HUCHZERMEYER, F.W.; HENTON, M.M.; KEFFEN, R.H. High mortality associated with megabacteriosis of proventriculus and gizzard in ostrich chicks. Vet. Rec., v.133, p.143-144, 1993.

MARINHO, M.; MEIRELES, M.V.; SOUZA A.V.G. Determinação da microflora do trato gastrintestinal de avestruzes (Struthio camelus) criados na região noroeste do estado de São Paulo, submetidas à necrópsia. Arq. Inst. Biol. São Paulo, v.71, p.267-271, 2004.

PHALEN, D.N. Diagnosis and management of Macrorhabdus ornithogaster (formerly megabacteria). Vet. Clin North Am: Exot Anim Pract., v.8, p.299-306, 2005.

PHALEN, D.N.; MOORE, R.P. Experimental infection of white-leghorn cockerels with Macrorhabdos ornithogaster (Megabacterium). Avian Dis., v.47, p.254-260, 2003.
RITCHIE, B.W.; HARRISON, G.J.; HARRISON, L.R. (eds): Avian Medicine: Principles and Application. Lake Worth, FL: Wingers Publishing, Inc., p.535-536, 662, 1997.

ROSSI, G: Possibility of infecting mammals with megabacteria isolated from birds [letter]. Vet Rec v.147, p.371-372, 2000.

ROSSKOPF, W. Digestive System Disorders. In: Rosskopf, W. e Woerpel, R. Diseases of Cage and Aviary Birds, W. $3^{\text {a }}$ ed., Baltimore, MD, EUA: Lea \& Febiger - Williams \& Wilkins, 1996, p. 436-448.

SCANLAN, C.M.; GRAHAM, D.L. Characterization of a gram-positive bacterium from the proventriculus of budgerigars (Melopsittacus undulatus). Avian Dis., v. 34, p.779-786, 1990.

SCHULZE, C.; HEIDRICH, R. Megabacteriaassociated proventriculitis in poultry in the state of Brandenburg, Germany. Deutsch Tierarztl. Wochenschr., v. 108, p.264-266, 2001.

SEGABINAZI, S.D.; FLÔRES, M.L.; KOMMERS, G.D. et al. Megabacteriose em emas (Rhea americana) no Estado do Rio Grande do Sul, Brasil. Ciênc. Rural, v.34, p.959-960, 2004.

TALLTREE, C. Megabacteria in budgies - A review of the literature. http://www.talltree.net/birds/ megabacteria.html. Acessado em 31 de maio de 2005.

TOMASZEWSKI, E.K.; LOGAN, K.S.; SNOWDEN, K.F. et al.. Phylogenetic analysis identifies the 'megabacterium' of birds as a novel anamorphic ascomycetous yeast, Macrorhabdus ornithogaster gen. nov., sp. Int J Syst Evol Microbiol., v.53, p.1201-1205, 2003.

VAN HERCK, H.; DUIJSER T.; ZWART P. et al. A bacterial proventriculitis in canaries (Serinus canaria). Avian Pathol., v. 13, p.561-572, 1984.

WERTHER, K.; SCHOCKEN-ITURRINO, R.P.; VERONA, C.E.S. et al. Megabacteriosis Occurrence in Budgerigars, Canaries and Lovebirds in Ribeirao Preto region - Sao Paulo State - Brazil. Rev. Bras. Cienc. Avic. [online]. mayo/ago. 2000, v.2, p.183-187. Disponible en la World Wide Web: $<$ http://www.scielo.br/scielo.php?script= sci_arttext\&pid=S1516-635X2000000200008\& lng $=$ es\&nrm=iso $>$. ISSN 1516-635X Acessado em 18 de maio de 2006. 